\title{
Ku Wenecji nowego średniowiecza. Wrocław między foresightem a strategią
} \#strategia \#foresight \#scenariusze przyszłości \#samorzad terytorialny \#gmina \#strategy \#foresight \#future scenarios \#local government \#commune

Artykuł opowiada o prowadzonych w latach 2015-2016 pracach nad koncepcjami dalszego rozwoju Wrocławia. W ich trakcie powstały scenariusze przyszłości miasta, które zakładały różne kierunki trendów społecznych, ekonomicznych i politycznych. Diagnozowany był bieżący stan głównych obszarów życia Wrocławia, w tym grożące im ryzyka. Analizowane były rozmaite pomysły na sprofilowanie miasta. Badania opinii społecznej pokazały, że mieszkańcom najbardziej podobają się trzy takie śmiałe wizje przyszłości: Wrocław jako jeden z pięciu wiodących ośrodków nauki i kultury w Europie Środkowej; Wrocław jako najlepsze i najpiękniejsze w Europie miasto-ogród; Wrocław jako Dolina Krzemowa Europy Środkowej. Dwa główne projekty, które przysłużyły się tym wszystkim badaniom i analizom to Foresight Społeczny Wrocław 2036/2056 oraz Strategia Wrocław 2030. Artykuł pokazuje związki między nimi.

The article tells about the work carried out in 2015-2016 on the concepts of Wrocław's further development. In their course, some scenarios of the city's future were created, assuming different directions of social, economic and political trends. The current status of the main areas of the city's life, including the risks posed to them, was diagnosed as well. Various ideas for profiling Wrocław were analyzed. The public opinion survey conducted at the time showed that the city's inhabitants like most the three following daring visions of the future: Wrocław as one of the five leading centres of science and culture in Central Europe; Wrocław as the best and most beautiful garden city in Europe; Wrocław as the Silicon Valley of Central Europe. The two main projects that have contributed to the implementation of these tasks are Social Foresight for Wroclaw 2036/2056 and Strategy for Wrocław 2030. The article focuses on the relationships between them.

Miasto. Pamięć i Przyszłość 1 (2017) ISSN 2543-621X

\section{OPEN ACCESS}

Citation: Medeksza Ł., Towards the Venice of the new Middle Ages. Wrocław between the foresight and strategy, „Miasto. Pamięć i Przyszłość: Wrocławski Rocznik Samorządowy" - No 1

https://doi.org/10.xxxxx

Editor: Katarzyna Uczkiewicz Received: October, 2016 Accepted: December, 2016

Published: December, 2016

Copyright: @ Ośrodek „Pamięć i Przyszłość" This is an open access article distributed under the terms of the Creative Commons Attribution-ShareAlike Licence, which permits unrestricted use, distribution, and reproduction in any medium, provided the original author and source are credited, with indications if any changes are made. All derivative works must be licensed under the same licence.

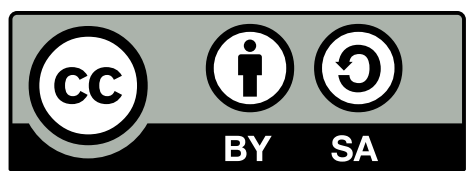




\section{Ku Wenecji nowego średniowiecza. Wrocław między foresightem a strategią}

Skoro przyszłość jest niepewna i groźna, rzeczywistość coraz bardziej rozproszona i wielowątkowa, a miasta to skomplikowane systemy, którymi nie da się zarządzać - to co możemy zrobić we Wrocławiu? Jakie strategie miejskie są w ogóle możliwe w tych trudnych czasach?

Mój tekst jest autorską refleksją na marginesie prac nad nową strategią Wrocławia oraz nad Foresightem Społecznym Wrocław 2036/2056. W części pierwszej pokrótce opiszę oba te projekty i ich efekty. W części drugiej przedstawię główne koncepcje i dylematy, jakie pojawiły się w ramach tych prac, wprowadzę też przenikające je kategorie „wielości”, „złożoności”, „rozproszenia”. W części trzeciej zaproponuję możliwe modele strategii miejskich i wskażę kilka dylematów, jakie rodzą się w związku z nową strategią Wrocławia.

\section{Foresight i strategia: co zdarzyło się w latach 2015-2016?}

Wiosną 2015 r. ruszyły prace nad nową strategią miasta`'. Roboczo została ona nazwana Strategią Wrocław 2030. Z ramienia władz miasta prace koordynuje Andrzej Łoś². Formalną uchwałę

Miasto. Pamięć i Przyszłość 1 (2016) ISSN 2543-621X o przystąpieniu do tego procesu Rada Miejska Wrocławia przyjęła w październiku 2015 r. ${ }^{3}$.

Przygotowanie diagnozy Wrocławia oraz samej strategii zostało zlecone zespołowi ekonomistów z Uniwersytetu Ekonomicznego we Wrocławiu, którymi kieruje Stanisław Korenik . Jednak prace nie są prowadzone wyłącznie w modelu eksperckim - są jednocześnie uspołecznione. W praktyce oznacza to przede wszystkim, że oficjalnym partnerem władz miasta w tym procesie jest od samego początku znany, lokalny ruch miejski - Towarzystwo Upiększania Miasta

1. Byłaby to trzecia po 1990 r. strategia Wrocławia. Pierwsza została przyjęta w 1998 r. Obecnie obowiązuje druga, z 2006 r. Strategia Wrocław w perspektywie 2020 plus.

2. W przeszłości m.in. wiceprezydent Wrocławia i marszałek Dolnego Śląska.

3. Uchwała nr XVII/323/15 Rady Miejskiej Wrocławia z dnia 15 października 2015 r. w sprawie przystąpienia do sporządzenia strategii rozwoju Wrocławia pod nazwą "Strategia Wrocław 2030": http:// wrosystem.um.wroc.pl/beta_4/webdisk/180716/0323ru07.pdf. Zob. też uzasadnienie uchwały: http://bip.um.wroc.pl/uploads/ files/Sesje_porzadki_7_kadencja/316-15\%20uzasadnienie.pdf. (wszystkie przytoczone w tekście linki były aktywne 4 I 2017).

4. Wraz ze swoimi współpracownikami był wcześniej autorem dwóch kolejnych wersji strategii integracji Aglomeracji Wrocławskiej (z lat 2001-2002 i 2011) oraz obowiązującej obecnie strategii dla tzw. ZIT WrOF (2015) - czyli Zintegrowanych Inwestycji Terytorialnych Wrocławskiego Obszaru Funkcjonalnego.

5. W latach 2015-2016 partnerem wspomagającym prace ze strony społecznej była także Fundacja Dom Pokoju. 
Wrocławia (TUMW)5 , a jednym z głównych narzędzi zbierania wiedzy o mieście była seria parunastu otwartych forów tematycznych, zorganizowanych między majem 2015 r. a wrześniem 2016 r. ${ }^{6}$

6. Każde forum obejmowało jedną lub dwie dziedziny (np. demografię, mieszkalnictwo, gospodarkę czy kulturę). Każde miało dwie osoby współprowadzące - jedna reprezentowała wrocławski samorząd, drugą był przeważnie naukowiec i/lub aktywista. Pełna lista forów wraz z linkami do materiałów, które zostały pozyskane w ich trakcie jest na stronie prac nad strategią: http://www.wroclaw.pl/strategia-rozwoju-wroclawia-2030/ forum-wroclawian-semanria-dyskusje-warsztaty.

7. Zob. J. Pluta, Mieszkańcy na temat bieżącej oceny potencjału Wrocławia i strategii rozwojowych miasta. Prezentacja wyników badań nad założeniami Strategii Wrocław 2030, http://www.wroclaw.pl/ strategia-rozwoju-wroclawia-2030/files/Wroclaw-2030-prezentacja-media-3.pdf - prezentacja przedstawiona 17 X 2016.

8. Koordynator: Łukasz Medeksza. Za uspołecznianie foresightu odpowiadała Kamila Kamińska. Projekt był częścią programu Miasto Przyszłości / Laboratorium Wrocław, którego kuratorem był Edwin Bendyk, a główną koordynatorką Anna Wyganowska-Błażejewska. Dobrym wprowadzeniem do tematyki foresightowej - a zarazem odpowiedzią na pytanie "czym jest foresight?" - jest: E. Bendyk, Foresight. Sztuka i techniki zarządzania przyszłością, Instytut Badań nad Gospodarką Rynkową, Gdańsk 2013, http://www.ibngr.pl/content/ download/1474/16065/file/Foresight-Sztuka_i_techniki_zarzadzania_przyszloscia.pdf.

9. Redaktor prowadzący Strategii dla Miasta Przyszłości: Łukasz Medeksza. Kolejne tomy mają odrębne tematy i redaktorów. W odwołaniach do poszczególnych tekstów z tych tomów, zamiast pełnego tytułu serii i tomu, będę stosował skrócony przypis wedle wzoru: SdMP, t. 1, s. ... . Oto lista tomów, wraz z nazwiskami redaktorów: Tom 0 - Wrocław. Rewers. Scenariusze miasta przyszłości (red. K. Kamińska, M. Pięta-Kanurska, A. Snitsaruk); Tom 1 - Miasta w nowym średniowieczu (red. G. Lewicki); Tom 2 - Między miłościq a polityka (red. M. Żakowska); Tom 3 - Miasto piękna i charakteru (red. I. Gajny); Tom 4 - Miasto mądre i samodzielne (red. T. Bojęć). Wydawcą jest Biuro Festiwalowe Impart 2016. (Gdy ten tekst był oddawany do druku, wersje elektroniczne tomów nie były jeszcze dostępne. Miały zostać umieszczone na nowej stronie programu Miasto Przyszłości / Laboratorium Wrocław, nad którą w styczniu 2017 r. pracowało Biuro Festiwalowe Impart 2016).

10. Ł. Medeksza, Foresightowe scenariusze przyszłości dla Wrocławia, [W:] SdMP, t. 0.

11. Blok tekstów Strategie, scenariusze, wizje [w:] SdMP, t. 0. Autorami tych scenariuszy są Małgorzata Pięta-Kanurska, Joanna Wyrwa, Wioletta Wrona-Gaj, Piotr Szymański, Łukasz Maślanka.

12. Blok tekstów W poszukiwaniu miasta przyszłości [W:] SdMP, t. 0. Autorami raportów, relacji i komentarzy w tej części są Kamila Kamińska, Mariusz Gaj, Agnieszka Wieszaczewska, Aleksandra Zienkiewicz, Hanna Janczak, Grzegorz Tymoszyk, Joanna Waszkiewicz, Maria Idzikowska, Tomasz Kasprzak. Efektownym
- w ich trakcie dyskutowali głównie urzędnicy, eksperci i aktywiści.

Istotne dla prac nad strategią były badania opinii przeprowadzone w czerwcu i lipcu 2016 r. na reprezentatywnej próbie tysiąca mieszkańców miasta7. Respondenci zostali zapytani m.in. o priorytety rozwoju miasta oraz wybierali między pięcioma krótkimi wizjami przyszłości Wrocławia - te dwa tematy omówię w następnym rozdziale tekstu.

Równolegle - pod skrzydłami Europejskiej Stolicy Kultury Wrocław 2016 - realizowany był projekt Foresight Społeczny Wrocław 2036/2056. Jego główne owoce zostały zebrane w pięciotomowej publikacji wydanej pod koniec 2016 r. pod szyldem Strategie dla Miasta Przyszłościp. W ramach foresightu powstały m.in.: wynikająca z prac z zaproszonymi ekspertami wstępna propozycja scenariuszy przyszłości dla miasta ${ }^{10}$; pakiet pięciu scenariuszy pogłębiających wizje Wrocławia, o które pytała wspomniana wyżej ankieta z czerwca i lipca 2016 r.11; zebrane podczas licznych warsztatów z mieszkańcami - w tym zwłaszcza z dziećmi - oddolne pomysły na Wrocław ${ }^{12}$; literackie wizje przyszłości Wrocławia' ${ }^{13}$. W następnym rozdziale wspomnę szerzej o foresightowych scenariuszach. Foresight zaowocował także badaniami potencjału kulturowego Wrocławia, przeprowadzonymi przez zespół ekspertów z Uniwersytetu Warszawskiego ${ }^{14}$.

W drugiej połowie 2016 r. była już gotowa strategiczna diagnoza miasta, autorstwa zespołu Stanisława Korenika ${ }^{15}$. Uwzględnia ona także dorobek wspomnianych już forów tematycznych.

Miasto. Pamięć i Przyszłość 1 (2016) ISSN 2543-621X 
Jej uzupełnieniem są propozycje diagnostyczne zebrane w grudniu 2016 r. w formie prezentacji przez TUMW ${ }^{16}$ oraz mój tekst Pytanie o Wrocław przyszłości - wstępne uwagi do diagnoz i analiz miasta, napisany pod sam koniec 2016 r. ${ }^{17}$.

W listopadzie 2016 r. prezydent Wrocławia powołał zespół ds. Strategii Wrocławia 203018. Jego zadaniem jest poprowadzenie dalszych prac nad tym dokumentem (przy zachowaniu ich mieszanego modelu: pisaniem tekstu nadal zajmuje się zespół Stanisława Korenika, strategia zaś ma zostać poddana kolejnym formom uspołeczniania w 2017 r.). Pierwsze szkice strategii omawiane były przez zespół w grudniu 2016 r. Zgodnie z założeniami, dokument powinien być przyjęty przez Radę Miejską Wrocławia w drugiej połowie 2017 r.

Na marginesie można odnotować, że symbolicznym momentem przecięcia prac nad strategią i nad foresightem była podsumowująca drugi z tych projektów konferencja Idea Wrocławia. Między foresightem a strategia, zorganizowana 28 listopada 2016 r., we wrocławskim Centrum Historii Zajezdnia ${ }^{19}$.

Od 2015 r. Wrocław jest terenem i tematem wielu badań, analiz, strategii. Dość powiedzieć, że trwają prace nad nowym Studium uwarunkowań i kierunków zagospodarowania przestrzennego gminy, a więc najważniejszym dla miasta dokumentem planistycznym. Zgodnie z założeniami ma on być spójny ze strategią ${ }^{20}$. W latach 2015-2016 prowadzona była także Analiza funkcjonalna osiedli Wrocławia ${ }^{21}$. Realizowane są kolejne edycje Wrocławskiego Budżetu Obywatelskiego, poddawane co roku publicznym

\section{Miasto. Pamięć i Przyszłość 1 (2016) ISSN 2543-621X}

dyskusjom i analizom. Regularnie badane były opinie mieszkańców na temat ESK2016. Powstawały tematyczne strategie i ich projekty - jak choćby przyjęta w 2015 r. Wrocławska Strategia Edukacyjna22 czy Przedsiębiorczy Wrocław 2030.

podsumowaniem tej części foresightu była tzw. konferencja dziecięca zorganizowana 16.11.2016. w Instytucie Pedagogiki Uniwersytetu Wrocławskiego przez Kamilę Kamińską. Zob. https://www. youtube.com/watch?v=5Uv-3iuvzEs.

13. Bloki tekstów Heterotopie miejskie - oddolne scenariusze oraz Korzenie i skrzydła miasta [w:] SdMP, t. O. Autorami opowiadań są M. Gruna, I. Witkowska, O. Chrebor, T.J. Sysło, H. Janczak, M. Ohia, K. Niepogodzińska, Z. Tyczyński i Y. Yurtsiv, P. Jargusz.

14. P. Dworzański, M. Grochowski, K. Gubański, B. Iwańczak, A. Świętochowska, K. Wereta, K. Wojnar, Diagnoza potencjału kulturalnego Wrocławia. Raport z realizacji pakietu zadań analityczno-badawczych i konsultacyjnych, Warszawa, sierpień 2016, materiał roboczy, niepublikowany, w posiadaniu autora.

15. Diagnoza Wrocławia, Wrocław, sierpień-wrzesień 2016, tekst niepublikowany, w posiadaniu autora.

16. K. Karabon, M. Karabon, Migawki z diagnozy Wrocławia, Konsultacje: P. Filar, Ł. Medeksza, Wrocław, grudzień 2016, prezentacja niepublikowana.

17. Ł. Medeksza, Pytanie o Wrocław przyszłości - wstępne uwagi do diagnoz i analiz miasta, tekst przygotowany w ramach Foresightu Społecznego Wrocław 2036/2056, niepublikowany. (Docelowo miał zostać umieszczony na nowej stronie programu Miasto Przyszłości / Laboratorium Wrocław, nad którą w styczniu 2017 r. pracowało Biuro Festiwalowe Impart 2016).

18. W zespole jest łącznie dziesięć osób. Kierownik: Andrzej Łoś, sekretarz: Łukasz Medeksza. Pełen skład i zakres zadań - zob. Zarządzenie nr 5702/16 Prezydenta Wrocławia z dnia 9 listopada 2016 r. w sprawie powołania zespołu ds. Strategii Wrocławia 2030, http://wrosystem.um.wroc.pl/beta_4/webdisk/187841/5702zp16. pdf.

19. Pełen zapis konferencji można znaleźć w YouTube: https:// www.youtube.com/watch?v=fNYw6erl9Jg. Głównym prelegentem był Jerzy Hausner, ekonomista, były wicepremier Rządu RP.

20. Pracami nad studium kieruje Tomasz Ossowicz z Biura Rozwoju Wrocławia. Jest zresztą od początku zaangażowany także w prace nad strategią. Niektóre działania na rzecz obu dokumentów prowadzone są wspólnie - tak było z niektórymi spośród wspomnianych w tekście otwartych forów tematycznych, przygotowywanymi wspólnie przez zespoły pracujące nad strategią i nad studium.

21. Zlecony przez władze miasta Fundacji Dom Pokoju interdyscyplinarny projekt, prowadzony głównie przez urbanistów i socjologów pod kierunkiem Izabeli Mironowicz.

22. Zob. http://wrosystem.um.wroc.pl/beta_4/webdisk/179742/0271ru07z.pdf. 


\section{Priorytety rozwoju miasta}

\section{'3n Wrocław} 2030

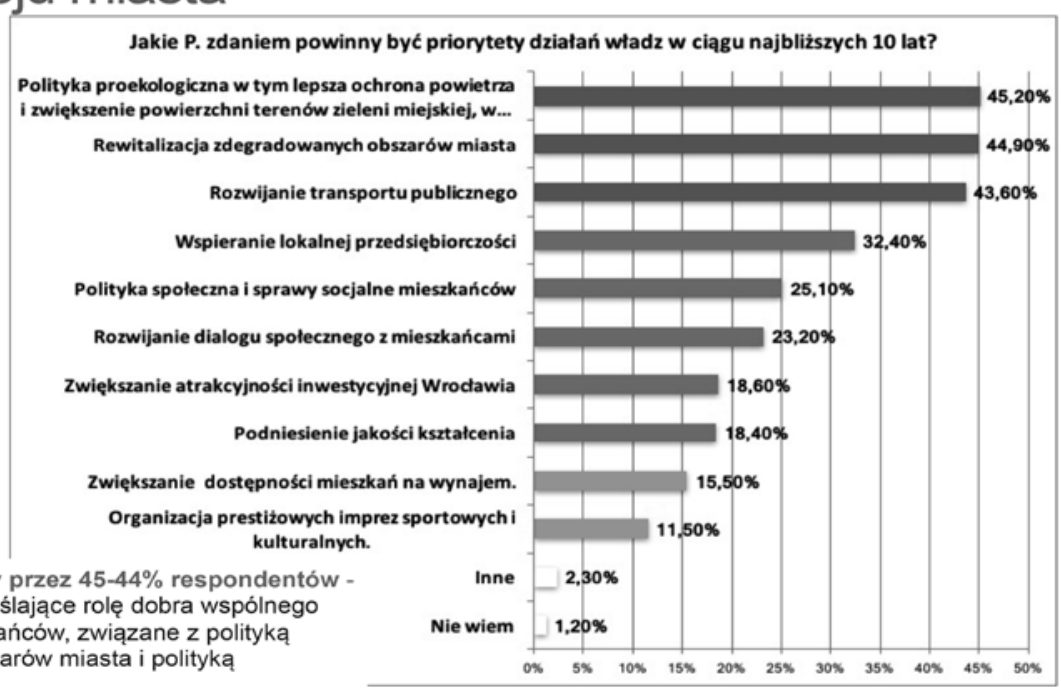

Pierwszy obszar - wskazywany przez 45-44\% respondentów tworzą „,cele miejskie" - podkreślające rolę dobra wspólnego w tworzeniu jakości życia mieszkańców, związane z polityką proekologiczną, rewitalizacji obszarów miasta i polityka

Drugi obszar - wskazywany przez 32-18\% mieszkańców tworzą „cele rozwoju i spójności społecznej” (gospodarcze i społeczne). Związane z przedsiębiorczością, edukacją, wsparciem społecznym oraz dialogiem społecznym.

Trzeci obszar - wskazywany przez 11-15\% respondentów tworzą ,"cele polityki mieszkaniowej i kulturalnej".

Rys. 1. Jakie powinny być priorytety władz Wrocławia? Slajd z prezentacji z wynikami przeprowadzonych w czerwcu i lipcu 2016 r. badań opinii wrocławian na temat przyszłości miasta (autor: Jacek Pluta)

Strategia Rozwoju Przedsiębiorczości Miasta Wrocławia, której projekt powstał w 2016 r. W tym samym roku, w ramach unijnego programu Urbact III, prowadzone były analizy i warsztaty na temat przyszłości ul. Świdnickiej - w tym z udziałem ekspertów międzynarodowych ${ }^{23}$.

\section{Wizje, scenariusze, niepewność przyszłości}

Jak już wspomniałem, w czerwcu i lipcu 2016 r. w ramach prac nad strategią zostały przeprowadzone badania opinii wrocławian.

23. Por. http://www.wroclaw.pl/biznes/urbact-iii-2016-we-wroclawiu-rozmawiali-o-ul-swidnickiej. Te warsztaty zainspirowały z kolei foresightowe opracowanie: I. Gajny, M. Dębek, Świdnicka A.D. 2056: handlowy kręgosłup metropolii [w:] SdMP, t. 3.

24. J. Pluta, op. cit.
Najciekawsza była część dotycząca przyszłości. A w niej zwłaszcza dwa tematy: priorytety rozwoju miasta oraz wizje przyszłości Wrocławia.

Odnosząc się do proponowanych priorytetów rozwoju, respondenci wyraźnie postawili na zieleń, rewitalizację i transport publiczny. Pokazuje to rysunek $1^{24}$.

Takie wyniki to sukces tzw. ruchów miejskich. Potwierdzają popularność ich agendy - stawiającej na jakość życia mieszkańców, w tym zwłaszcza właśnie na zieleń i transport publiczny (nie zaś na ekonomię, duże inwestycje czy politykę

Miasto. Pamięć i Przyszłość 1 (2016) ISSN 2543-621X 
'30 Wrocław

\section{Oczekiwana wizja miasta - marka Wrocław} 2030

Wizje rozwoju miasta

\begin{tabular}{|c|c|}
\hline $\begin{array}{l}\text { Jaką wizją miasta winny kierować się władze podejmując decyzję o kluczowym znaczeniu dla miasta? } \\
\text { Jakim miastem powinien byc Wrocław w } 2030 \text { roku? }\end{array}$ & $\begin{array}{l}\text { Procent respondentów } \\
n=1000\end{array}$ \\
\hline $\begin{array}{l}\text { Jeden z pięciu wiodących ośrodków nauki i kultury w Europie Środkowej: z Uniwersytetem Wrociawskim } \\
\text { jako jedną z najlepszych uczelni w tej części kontynentu, z przynajmniej jednym czasopismem publicystycznym o randze } \\
\text { przynajmniej krajowej, z przynajmniej jedną instytucją kultury lub festiwalem o randze światowej, z jasno } \\
\text { wytyczonym celem, że w ciagu np. ćwierć wieku chcemy mieć Nobla z literatury lub Oscara. }\end{array}$ & 28,1 \\
\hline $\begin{array}{l}\text { Najlepsze i najpiękniejsze w Europie miasto-ogród: zatopione w zieleni samorząne osiedla; } \\
\text { główna gospodarcza specjalizacja to produkcja i usługi związane z zielenią, kwiatami, miejskim rolnictwem, } \\
\text { przetwórstwem żywności, upiększaniem przestrzeni itp.; prężny klaster żywnościowy; ogromna rola uczelni } \\
\text { i kierunków zajmujących się przyrodą, żywnością, biotechnologią, krajobrazem, przestrzenią, pięknem. }\end{array}$ & 26,5 \\
\hline $\begin{array}{l}\text { Dolina Krzemowa Europy Środkowej: Miasto zapleczem programistycznym ikoncepcyjnym dla publicznych } \\
\text { e-usług, z prototypowymi wdrożeniami w samym Wroclawiu. Opcjonalnie: także zaplecze badawczo-rozwojowe } \\
\text { zaawansowanego technologicznie przemysłu obronnego. }\end{array}$ & 23,8 \\
\hline Miasto spotkań, stawiające na duże imprezy i potencjały zewnętrzne poprzez ściąganie turystów i dużych inwestorów. & 15 \\
\hline $\begin{array}{l}\text { Jeden z najważniejszych portów transportowych na Nowym Jedwabnym Szlaku łączącym Chiny } \\
\text { z Europa: z zapleczem logistycznym, handlowym, produkcyjnym, rozrywkowym. }\end{array}$ & 6,6 \\
\hline Ogólem & 100 \\
\hline
\end{tabular}

Dotychczasowa wizja Wrocławia - miasta spotkań, kształtująca myślenie o mieście w ostatnim ćwierćwieczu, to wizja do pewnego stopnia już spełniona i jako taka nie odpowiada wyzwaniom rozwojowym i ambicjom samych mieszkańców.

Podstawowym problemem jest jednak to, że oczekiwanie nowego rozdziału wrocławskiej narracji nie jest związane z jakąś jedną wizją, co uwidacznia się we wskazanych preferencjach, z których wynika, że żadna z wyróżnionych nie ma pozycji dominującej.

Rys. 2. Pięć roboczych wizji przyszłości Wrocławia. Slajd z prezentacji z wynikami przeprowadzonych w czerwcu i lipcu 2016 r. badań opinii wrocławian na temat przyszłości miasta (autor: Jacek Pluta)

promocyjną bazującą na dużych eventach). Nic dziwnego, że na tę część badania chętnie powołuje się teraz najbardziej znany wrocławski ruch miejski, czyli wspomniany już na początku tekstu TUMW25.

Niezwykle inspirujący okazał się wątek wizji przyszłości. Na potrzeby badania sformułowanych zostało pięć takich roboczych wizji Wrocławia. Ich tytuły to: 1. Jeden z pięciu wiodących ośrodków nauki i kultury w Europie Środkowej; 2. Najlepsze i najpiękniejsze w Europie miasto-ogród; 3. Dolina Krzemowa Europy Środkowej; Miasto. Pamięć i Przyszłość 1 (2016) ISSN 2543-621X
4. Miasto spotkań; 5. Jeden z najważniejszych portów transportowych na Nowym Jedwabnym Szlaku łączącym Chiny z Europą. Dodatkową wartością tego zestawu jest to, że owe wizje nie wykluczają się wzajemnie - można je łączyć w różne kombinacje. Niemniej respondenci wyraźnie wskazali, które wizje ich przekonują, a które nie. Na rysunku 2. są nie tylko nazwy wizji, ale też ich krótkie opisy - oraz oczywiście wyniki badania ${ }^{26}$.

Największym zaskoczeniem jest słaby wynik wizji nazwanej „Miasto spotkań”, nawiązującej do
25. Por. K. Karabon, M. Karabon, op. cit.

26. Slajd za: J. Pluta, op. cit. 
dotychczasowej polityki władz Wrocławia. Jest to o tyle kłopotliwe, że hasło "Miasto spotkań" jest mutacją strategicznej misji Wrocławia: „Wrocław miastem spotkania - miastem, które jednoczy". O dylematach, które w związku z tym powstały wspominam pod sam koniec tekstu.

Jak te wyniki mają się do foresightu?

Po pierwsze - wskazane przez badanych mieszkańców priorytety rozwoju są zbieżne z marzeniami i nadziejami wyrażanymi przez uczestników foresightowych warsztatów, w tym przez dzieci27 . Wyraźnie jednak kontrastują z akcentowaną przez współpracujących z foresightem ekspertów i aktywistów niepewnością wobec przyszłości28.

Po drugie - w listopadzie 2016 r., w ramach foresightu, rozwinęliśmy i pogłębiliśmy opisy cytowanych wyżej pięciu roboczych wizji przyszłości Wrocławia. Autorzy tekstów na ten temat ${ }^{29}$ próbowali nie tylko proponować konkretne rozwiązania, które mogłyby przyczynić się do realizacji wizji, ale też wskazywali czynniki ryzyka, korzystając przy tym z zestawu pięciu trendów (rywalizacja między miastami; rosnąca rola kobiet; narastanie konfliktu aksjologicznego; policentryzacja i rozrastanie się aglomeracji; zmierzch demokracji opartej na papierze)

27. Zob. blok tekstów W poszukiwaniu miasta przyszłości [w:] SdMP, t. 0, op. cit. Temat zieleni w wypowiedziach dzieci komentuje Aleksandra Zienkiewicz z TUMW i Akcji Miasto: A. Zienkiewicz, Zieleń dzieci, [w:] SdMP, t. 0.

28. Por. M. Pięta-Kanurska, Wprowadzenie - w bloku tekstów Strategie, scenariusze, wizje [w:] SdMP, t. 0, op.cit. Zob. też moje wprowadzenie do SaMP: $Ł$. Medeksza, Strategie dla Miasta Przyszłości, [w: S SdMP, t. 0. Także Ł. Medeksza, Foresightowe scenariusze..., op. cit.

29. Zob. cytowany już blok tekstów Strategie, scenariusze, wizje, [w:] SdMP, t. 0, op. cit.

30. W Świeradowie-Zdroju, 4-6 XI 2016.

31. P. Szymański, Naukowe nie-miejsce [w:] SdMP, t. 4.

32. Ł. Medeksza, Foresightowe scenariusze..., op. cit. oraz czterech czynników niepewności (poziom niezależności i samodzielności miast; wojna, konflikt, przełom; rozwarstwienie społeczne i przestrzenne; wzrost znaczenia populistów), wskazanych przez uczestników foresightowych warsztatów w listopadzie $2016 r{ }^{30}$. Autorzy tych scenariuszowych ćwiczeń przeważnie podchodzą pozytywnie do opisywanych wizji. Trzeba jednak odnotować ciekawy, bardzo sceptyczny głos Piotra Szymańskiego z TUMW (acz wyrażony poza wspomnianym blokiem scenariuszy). Jego zdaniem Wrocław nie ma obecnie wystarczającego potencjału na polu nauki, by można było uznać jego wizję jako „jednego z pięciu wiodących ośrodków nauki i kultury w Europie Środkowej" za realistyczną ${ }^{31}$. A jest to - przypomnę - wizja, która uzyskała największą popularność w badaniu prowadzonym na potrzeby strategii.

Po trzecie - punktem dojścia foresightu w jego części eksperckiej było stworzenie zestawu scenariuszy przyszłości. Tworząc ich finalne propozycje ${ }^{32}$, przyjąłem kilka założeń: 1. Warto uwzględnić nie tylko wspomniany już rozziew między oczekiwaną przez mieszkańców poprawą jakości życia a obawami wyrażanymi przez ekspertów i aktywistów, ale też przewijające się przez wiele foresightowych dyskusji i tekstów kategorie "miłości” i „wielości”; 2. Scenariusze mogą być wyrazem rozmaitych paradygmatów rozwoju (lub post-rozwoju); 3. Wrocław traktuję jako przede wszystkim podmiot, a nie jedynie przedmiot możliwych przyszłych przemian (jest to więc założenie ofensywne, które może być przydatne w układaniu przyszłej strategii);

Miasto. Pamięć i Przyszłość 1 (2016) ISSN 2543-621X 


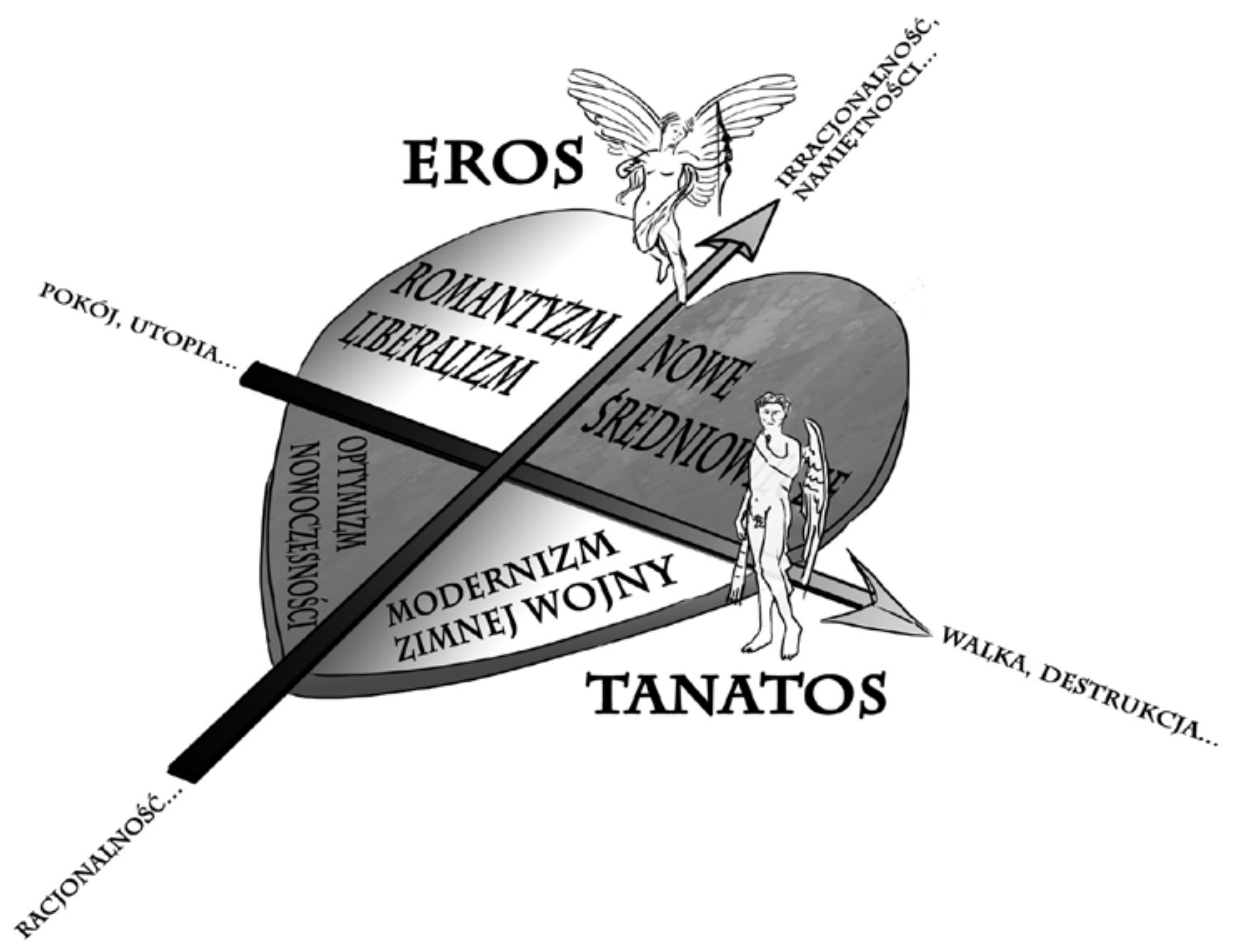

Rys 3. Foresightowe scenariusze dla Wrocławia - schemat (rys. Michał Ciesielski)

4. W każdym scenariuszu należy uwzględnić m.in. takie komponenty, jak: sytuacja zewnętrzna i wewnętrzna miasta, wartości, przestrzeń, zasoby, model governance, ekonomia, charakterystyczne wydarzenia, charakterystyczny typ wrocławianina, charakterystyczne obiekty w przestrzeni, dominująca estetyka. By ułożyć scenariusze, posłużyłem się prostym schematem dwóch osi przecinających się pod kątem prostym. Jedną nazwałem osią Erosa, drugą - osią Tanatosa. Opisałem je tak:

Oś Erosa to „ oś sposobów i motywów działania. Na jej jednym krańcu umieszczam motywacje irracjonalne - wartości, interesy, namiętności. To właśnie tu rozciąga się m.in. królestwo Erosa.
Na jej drugim krańcu lokuję motywacje racjonalne - w tym rozum praktyczny. Nie wartościuję żadnego z krańców osi. Przymiotnik »irracjonalny« nie jest pejoratywny, podobnie jak przymiotnik »racjonalny« nie jest pozytywny. Należy je rozumieć czysto opisowo (co oczywiście nie musi przeszkadzać zwolennikom racjonalizmu i ich oponentom preferującym irracjonalizm w adekwatnym wartościowaniu obu krańców osi)"33.

Oś Tanatosa to „oś aktualnych i/lub zamierzonych stanów rzeczywistości. Na jej jednym krańcu umieszczam konflikt, walkę, zniszczenie - a więc m.in. królestwo Tanatosa, śmierci. Na drugim krańcu - pokój, idyllę, utopię, harmonię,
Miasto. Pamięć i Przyszłość 1 (2016) ISSN 2543-621X
33. Ibidem. 
ale też np. dbałość o zdrowie. Polityka rozumiana jako konflikt będzie bliżej Tanatosa, zaś ta bazująca na deliberacji, partycypacji i szukaniu consensusu - bliżej krańca przeciwległego, pokojowego. Ta oś pokazuje wspomniany wcześniej rozdźwięk między utopijnymi oczekiwaniami mieszkańców Wrocławia a czarnowidztwem ekspertów i aktywistów ostrzegających przed wojnami i konfliktami"34.

Osie wyznaczają cztery pola. Każde z nich to jeden scenariusz. Oto one - wraz ze wskazaniem usytuowania względem obu osi („E" to oś Erosa, „T" - Tanatosa; plus oznacza umiejscowienie na tych ich krańcach, które nazwałem wcześniej „królestwami” obu bóstw; minus oznacza oczywiście umiejscowienie na krańcach przeciwnych): 1. Romantyzm i/lub liberalizm [E+/T-]; 2. Nowe średniowiecze $[\mathrm{E}+/ T+]$; 3. Modernizm Zimnej Wojny $[\mathrm{E}-/ \mathrm{T}+] ;$ 4. Optymizm nowoczesności [E-/T-]. Uzyskany tą drogą schemat widać na rysunku 3.

Scenariusze są opisane w moim tekście w Strategiach dla Miasta Przyszłości35. Wśród ich najważniejszych haseł można wymienić: 1. Romantyzm i/lub liberalizm - Unia Europejska

\section{Ibidem \\ 35. Ibidem.}

36. W trakcie wspomnianych już warsztatów foresightowych w Świeradowie-Zdroju (4-6 XI 2016) powstał inny wariant tego schematu. Jedna oś rozciągała się między autonomią a zanikiem autonomii (w tym wypadku owa autonomia dotyczyła przede wszystkim miast, a więc głównie Wrocławia), druga zaś - między pokojem a konfliktem. W ten sposób powstały oczywiście cztery pola. W każdy z nich wpisywane były konspekty scenariuszy, które wykorzystywały pięć wspomnianych już trendów oraz cztery czynniki niepewności.

37. Tomasz Kasprzak, Fantazmaty, narracje, symbole. Oddolne scenariusze przyszłości Wrocławia - głos mieszkańców, [w:] SdMP, t. 0, s. 112-114.

38. Ibidem. pogłębionej demokracji i wolności gospodarczej; autonomia wspólnot; 2. Nowe średniowiecze polityczny rozpad świata, groźba wojen; Wrocław lawiruje i prowadzi własną dyplomację; 3. Modernizm Zimnej Wojny - rozpad polityczny świata, powrót państw narodowych; duże ryzyko wojny światowej, militaryzacja; 4. Optymizm nowoczesności - utrzymanie dotychczasowego status quo, ale więcej zieleni i partycypacji; ten sam, co dotąd, optymistyczny paradygmat rozwojowy.

Nie ma odrębnych scenariuszy dla 2036 i 2056 r. (te dwie daty pojawiają się w tytule foresightowego projektu). Roboczo zakładam, że w 2056 możemy mieć do czynienia albo ze wzmocnieniem scenariusza z 2036, albo ze zmianą - na inny z tej samej puli36.

Swoją propozycję foresightowych scenariuszy przedstawił Tomasz Kasprzak na podstawie wyników współprowadzonej przez siebie serii warsztatów z różnymi grupami mieszkańców. Jego pierwsza oś to „continuum pomiędzy otwarciem a zamknięciem miasta na odmienność kulturową, społeczną, etniczną, otwartość na zmianę (Wrocław - miasto spotkań), czyli Wrocław otwarty versus zamknięty"37. Druga oś to „oś zasobów i infrastruktury - continuum od dostępności i przyjazności infrastruktury [...] do miasta bez ludzi [...]. Nieco inaczej można tę oś opisać jako napięcie pomiędzy podejściem prorynkowym w myśleniu o przestrzeni miasta i podejściem prowspólnotowym w organizacji przestrzeni"38. W rezultacie powstały cztery propozycje scenariuszy: „skandynawska idylla”, "ogród z wysokim murem”, „twierdza z metalu

Miasto. Pamięć i Przyszłość 1 (2016) ISSN 2543-621X 
i szkła” oraz "bazar na skrzyżowaniu kultur"39. Nie zostały one rozwinięte, ale same ich nazwy pokazują cztery możliwe modele miasta, albo - inaczej mówiąc - cztery możliwe modele przyszłej polityki planistycznej.

Również w ramach prac nad strategią zespół Stanisława Korenika rozważa trzy scenariusze dla Wrocławia: optymistyczny (szybki rozwój, ekspansja, rozkwit), neutralny (kontynuacja dotychczasowych tendencji), pesymistyczny (cofanie się, spowolnienie rozwoju) ${ }^{40}$.

Nad tymi wszystkimi ustaleniami unosi się niepewność wobec przyszłości. Z jednej strony - spowodowana jest ona rosnącymi komplikacjami w polityce globalnej (terroryzm w zachodnich miastach, wojna na Ukrainie, migracje do Europy z południa i ze wschodu, odrodzenie nacjonalizmów w Unii Europejskiej, Brexit, triumf Donalda Trumpa w USA, geopolityczna wolta Turcji...). Z drugiej strony - do pewnego stopnia może wynikać z samej metodologii foresightu, który zwraca przecież uwagę na znaczenie tendencji pozornie marginalnych i na nieprzewidywalność przyszłości ${ }^{41}$ (acz trzeba odnotować, że owa niepewność wybrzmiewa również w pracach nad nową strategią miasta, czego przejawem są choćby wspomniane scenariusze, które zakłada zespół Stanisława Korenika).

Tej niepewności sprzyjają zaostrzające się konflikty o charakterze politycznym i światopoglądowym - w Polsce i w samym Wrocławiu. W tym ostatnim wypadku możemy mieć

Miasto. Pamięć i Przyszłość 1 (2016) ISSN 2543-621X 61 do czynienia z początkiem walki o schedę po prezydencie Rafale Dutkiewiczu, który jesienią 2016 r. ogłosił, że nie zamierza startować w wyborach prezydenckich w 2018 r. ${ }^{42}$.

Spory dotyczą także wizji polskich miast. Rosnące od kilku lat w siłę ruchy miejskie postulują odejście od polityki zorientowanej wyłącznie na ciągłą poprawę wskaźników ekonomicznych (typu wzrost PKB) i na wielkie eventy - a w zamian proponują politykę zorientowaną na poprawę jakości życia mieszkańców i ich empowerment w roli obywateli. Ten spór dotarł także do Wrocławia, acz został częściowo skanalizowany poprzez zaproszenie zwolenników obu tych koncepcji - a więc zarówno tej akcentującej rolę ekonomii i dużych inwestycji, jak i przedstawicieli ruchów miejskich - do wspólnej pracy nad nową strategią.

Idei empowerment i wprowadzaniu służących mu narzędzi - takich jak procedury partycypacyjne - towarzyszą postulaty decentralizacji miasta i przekazywania odpowiedzialności za różne obiekty, przestrzenie czy zadania zainteresowanym mieszkańcom (zorganizowanym lub nie). Formułowane są zarówno przez aktywistów (na przykład: starania o przekształcenie kamienicy na Wyspie Słodowej 7 w niezależny ośrodek kultury ${ }^{43}$ ), jak i przez ekspertów (przykładem są bardzo podobne konkluzje

39. Ibidem.

40. Materiały robocze, niepublikowane, w posiadaniu autora tekstu.

41. Por. E. Bendyk, op. cit., str. 11.

42. O sytuacji politycznej Wrocławia - jako o możliwym końcu pewnej epoki - piszę szerzej w: Ł. Medeksza, Pytanie o Wrocław przyszłości..., op. cit.

43. Por. Ł. Medeksza, Fenomen wrocławskiej Wyspy Słodowej: starcie modeli użytkowania przestrzeni publicznej, [W:] „Człowiek i Środowisko", 39(2) 2015, https://czlowiekisrodowisko.igpim.pl/wp-content/ uploads/2016/06/04-Medeksza.pdf. 
Analizy funkcjonalnej osiedli Wrocławia ${ }^{44}$ oraz z przeprowadzonych w ramach foresightu badań potencjału kulturowego Wrocławia ${ }^{45}$ w obu przypadkach autorzy proponują decentralizację i przekazanie odpowiednich narzędzi działania oddolnym środowiskom, by te mogły „organicznie" tworzyć nową, quasi-instytucjonalną i/lub twórczą tkankę miasta).

Kategorią świetnie nadającą się do opisu tak właśnie pojmowanej, rozpraszającej się i wewnętrznie skonfliktowanej rzeczywistości jest „wielość". To termin znany w humanistyce (choćby dzięki tzw. postoperaistom). W jednym z tekstów, które powstały w ramach foresightu piszę o niej tak: "Czy nam się to podoba, czy nie, żyjemy w czasach faktycznego postmodernizmu, w których miejsce dominujących ośrodków władzy, bogactwa i ideologii zajęła - no właśnie - wielość nurtów, tendencji, zasobów i miejsc oddziaływania". Ponieważ owa wielość jest zarazem „aktywna, procesualna i zmienna”, nazywam ją wielością „pulsującą"46.

W zasadzie o tym samym mówi teza o złożoności systemów, w których poruszamy się

44. Izabela Mironowicz, Analiza funkcjonalna osiedli Wrocławia, Fundacja Dom Pokoju, Wrocław 2016, materiał niepublikowany, w posiadaniu autora.

45. P. Dworzański et al, op. cit.

46. Ł. Medeksza, Kurator wielości, [W:] SdMP, t. 2.

47. E. Bendyk, op. cit., str. 11.

48. Ibidem, s. 57. Podany jest tam pozytywny przykład Shella, który dzięki stosowaniu foresightu "jako jedyna z wielkich firm sektora energii nie dał się zaskoczyć kryzysowi naftowemu".

49. Ibidem, str. 55-56. Zob. też L. Freedman, Strategy. A history, Oxford University Press 2013, str. 160-161.

50. Zob. np. V. Vinge, The Coming Technological Singularity: How to Survive in the Post-Human Era, VISION-21 Symposium sponsored by NASA Lewis Research Center and the Ohio Aerospace Institute, March 30-31, 1993, http://www-rohan.sdsu.edu/faculty/vinge/ misc/singularity.html.

51. Wspomniana już wcześniej wrocławska urbanistka, w 2016 r. współpracowniczka foresightu, a zarazem koordynatorka prac nad Analiza funkcjonalna osiedli Wrocławia. i które badamy. To właśnie ona wpływa na nieprzewidywalność przyszłości: „cechą rozwoju cywilizacyjnego jest wzrost złożoności struktur społeczno-gospodarczych" - tłumaczy Edwin Bendyk. - „Jednocześnie sam rozwój w coraz większym stopniu zależy od intensywności wykorzystania wiedzy i wynikających z niej innowacji. W konsekwencji przyszłość staje się coraz mniej uchwytna, a liczba nietrafionych prognoz zdaje się tylko potwierdzać ograniczony sens futurystyki"47. Nic dziwnego, że myśl foresightowa karmi się przykładami nieprzewidzianych zawczasu wstrząsów z przeszłości - takich jak kryzys naftowy w 1973 r. ${ }^{48}$ Natomiast największym wyzwaniem w tym nurcie (czy sposobie) myślenia jest konceptualizowanie dramatycznych przełomów, które jeszcze nie nadeszły - takich jak wojna termojądrowa, analizowana w latach pięćdziesiątych i sześćdziesiątych przez jednego z prekursorów myśli foresightowej, Hermana Kahna ${ }^{49}$, czy koncepcja tzw. singularity, osobliwości, a więc takiego momentu w rozwoju technologii, po którym nic już nie będzie takie jak przedtem (bo np. roboty przejmą kontrolę nad światem) ${ }^{50}$.

O mieście jako systemie złożonym, otwartym i ciągle zmiennym pisze Izabela Mironowicz ${ }^{51}$ w Modelach transformacji miasta - książce wydanej pod koniec 2016 r. Jej zdaniem „każdy stan lokalnej równowagi, jaki osiągną [miasta], jest niestabilny". W rezultacie „nie jesteśmy w stanie przewidzieć przyszłego stanu miasta", a więc także „nie jesteśmy w stanie przewidzieć reakcji miasta na wdrażane polityki i projekty". Innymi słowy:

Miasto. Pamięć i Przyszłość 1 (2016) ISSN 2543-621X 
„nie sposób jest przewidzieć skutków interwencji urbanistycznej i ta niepewność jest immanentną cechą systemu"52. Tak samo uważa Piotr Lorens. Ten współczesny gdański urbanista przekonuje, że „model współczesnego miasta” można opisać jako „strukturę podzieloną, zdefragmentowaną i znacznie mniej czytelną od jej modernistycznego odpowiednika. [...] W efekcie forma przestrzenna miasta [...] nie jest do końca przewidywalna"53.

Złożoność systemów miejskich jest stałym wyzwaniem przy pracach nad strategiami miast. Za przejawy zwrotu od prostoty ku złożoności/wielości należy uznać takie zjawiska we współczesnej polityce i teorii rozwojowej jak przejście z koncepcji rozwoju pojmowanego jako wzrost ekonomiczny do koncepcji rozwoju zrównoważonego - a więc uwzględniającego nie tylko ekonomię, ale też inne dziedziny i uwarunkowania (np. akcentującego sferę społeczną i środowisko naturalne), czy przejście z modelu zarządzania top-down (np. menedżerskiego) ku modelowi multi-level governance, zakładającego współistnienie wielu podmiotów, w różnych relacjach, na różnych szczeblach ${ }^{54}$. Złożoność rośnie, gdy do klasycznego, prostego wskaźnika strategicznego typu wzrost PKB per capita dołączamy wskaźnik mierzący poziom jakości życia (tak właśnie zrobili autorzy Długookresowej Strategii Rozwoju Kraju 2030). Ta złożoność jest tym większa, że drugi ze wspomnianych wskaźników jest sam w sobie złożony - tworzy go grupa wybranych wskaźników szczegółowych. Mało tego. Złożoność rośnie jeszcze bardziej, gdy zdamy sobie sprawę, że możliwe są zarówno różne drogi prowadzące do wzrostu PKB (dylematem z tej

Miasto. Pamięć i Przyszłość 1 (2016) ISSN 2543-621X 63 dziedziny jest pytanie o wzajemne relacje tzw. potencjałów egzogenicznych i endogenicznych), jak i różne możliwe sposoby rozumienia jakości życia - a więc i rozmaite wskaźniki służące jej badaniu55.

Złożoność przenika również metodologie badania tych wszystkich zjawisk. Jest więc nie tylko cechą systemów, ale i sposobem ich poznania, opisu, interpretacji. Jak zauważa Simona Piattoni, multi-level governance to także „multi-level concept", czyli wieloszczeblowa koncepcja, ponieważ „łączy różne wymiary analiz i stawia różne rodzaje pytań"56. Także foresight wpisuje się w tak pojętą złożoność, gdyż nie jest on jedynie - jak podkreśla Edwin Bendyk - „zwykłym pudełkiem z narzędziami, które odsłonią przyszłość, lecz technologią intelektualną wymagającą zarówno wykorzystania formalnych technik, jak i postaw oraz kompetencji osób i zespołów stosujących te techniki". Jest "połączeniem technik o charakterze ilościowym, odwołujących się do mniej i bardziej twardych założeń teoretycznych potwierdzających poznawczy walor tych metod, jak i technik jakościowych, polegających na współpracy interesariuszy przyszłości w procesie jej opisywania, odkrywania i kreowania"57. Stąd właśnie tak bogaty, opisany wcześniej, zestaw

52. I. Mironowicz, Modele transformacji miast, Oficyna Wydawnicza Politechniki Wrocławskiej, Wrocław 2016, s. 90-91.

53. P. Lorens, Współczesne trendy zmian w strukturze i funkcjonowaniu miast, [w:] (red.) P. Lorens, I. Mironowicz, Wybrane teorie wspótczesnej urbanistyki, Akapit-DTP, Gdańsk 2013, s. 27-28.

54. W tej ostatniej kwestii zob. Ł. Medeksza, I. Mironowicz, Nowe modele zarzadzania terytorialnego [w:] „Biuletyn KPZK PAN”, nr 257-258 / 2015, http://bkpzk.czasopisma.pan.pl/images/data/ bkpzk/wydania/No_257_258_2015/4-Medeksza.pdf.

55. Przegląd tych ostatnich daje: I. Mironowicz, op. cit., str. 50-73.

56. S. Piattoni, The Theory of Multi-level governance. Cenceptual, empirical, and normative challenges, Oxford University Press, 2010, str. 26.

57. E. Bendyk, op.cit., str. 11, 26. 
dróg dochodzenia do rozmaitych scenariuszy przyszłości oraz form ich przekazu, jaki zastosowaliśmy we wrocławskim foresighcie. Wypowiedziom eksperckim i danym towarzyszą narracje oddolne i literatura. Inspiracją w tym zakresie był dla wrocławskiego foresightu zrealizowany w poprzedniej dekadzie program Glasgow 2020, którego efektem jest właśnie przede wszystkim zbiór opowiadań o przyszłości tego szkockiego miasta ${ }^{58}$. Podobnego rodzaju projekt zrealizował w latach 2008-2010 Amsterdam na potrzeby dziesiątego planu generalnego dla miasta Amsterdam 2040. Także i tam lokalne władze postawiły na budowanie opowieści o mieście, z udziałem zainteresowanych mieszkańców, w tym dzieci ${ }^{59}$. „Strukturalna wizja [Amsterdamu] jest silna, urozmaicona i przekonująca właśnie dzięki tej różnorodności idei i opowieści - różnorodność oddaje sprawiedliwość złożoności dużego miasta" - tłumaczy Zef Hemel, opisując prace nad tym projektem. I wprost odwołuje się do takich wartości jak nie tylko różnorodność, ale i autonomia i decentralizacja, posiłkując się przy tym myślą Jamesa Surowieckiego, jednego z apostołów koncepcji tzw. mądrości tłumu, która przyświecała m.in. społecznościowemu internetowi - Web 2.060. Trudno się dziwić, że Hemel

58. Zob. G. Hassan, M. Mean, C. Tims, The Dreaming City: Glasgow 2020 and the power of mass imagination, Demos, London 2007.

59. Por. Z. Hemel, Open Planning for a Liveable Amsterdam 20042011, tekst w posiadaniu autora. Dziękuję Izabeli Mironowicz za zwrócenie mi uwagi na to przedsięwzięcie.

60. Ibidem, s. 14-15.

61. P. Feyerabend, Against Method, Verso, 1993, s. 21. Tłum. własne.

62. Dobrym wprowadzeniem do tych sporów i dylematów jest: J. Nederveen Pieterse, Development Theory. Second Edition, SAGE, Los Angeles, London, New Delhi, Singapore, Washington DC, 2015, zwłaszcza s. 1-18.

63. Ibidem. chętnie porównuje projekt Amsterdam 2040 z Wikipedią. Cały ten zwrot ku metodologicznej wielości można uznać za realizację zaproponowanego jeszcze w latach siedemdziesiątych przez Paula Feyerabenda modelu "teoretycznego anarchizmu", w którym wiedza nie jest stopniowym dochodzeniem do prawdy, ale "wciąż rosnącym oceanem wzajemnie nieprzystajacych alternatyw", gdzie obok teorii jest miejsce także np. na bajki i mity ${ }^{61}$.

W tym kontekście znacznie łatwiej jest zrozumieć kryzys paradygmatu - czy kategorii „rozwoju”, przyjmowanego często (zwłaszcza w prawie unijnym i krajowym oraz w oficjalnych dokumentach produkowanych przez rządy i samorządy) za bezdyskusyjny pewnik. Można długo dyskutować, czy faktycznie rozwój „skończył się" (i żyjemy w erze „postrozwoju”), bo okazał się iluzją lub wręcz oszustwem skrywającym interesy jakichś wielkich sił politycznych i ekonomicznych, czy też nadal ma on sens - tyle że w jakiejś nowej wersji, np. jako narzędzie poszerzania zakresu indywidualnych możliwości decydowania o własnym losie (jak proponował Amartya Sen) ${ }^{62}$. W każdym razie trudno obecnie odwoływać się do kategorii rozwoju, nie precyzując, co dokładnie przez nią rozumiemy. Jak wykazał Jan Nederveen Pieterse, jest ona sama w sobie wielościowa, wieloszczeblowa, złożona, bo obejmuje liczne perspektywy badawcze, łączy praktykę z teorią, wiąże się z rozmaitymi interesami różnych aktorów ${ }^{63}$. Stąd zaproponowana przez tego autora bardzo prosta i elastyczna definicja „rozwoju” jako "zorganizowanej interwencji

Miasto. Pamięć i Przyszłość 1 (2016) ISSN 2543-621X 
w sprawy publiczne, prowadzonej na podstawie jakiegoś standardu poprawy [stanu rzeczy]"64.

Wielodziedzinowe rozproszenie i złożoność to powód, dla którego nasze czasy bywają nazywane w literaturze nowym średniowieczem. Nie należy tego porównania traktować jako postulatu powrotu do średniowiecza - ale raczej jako kolejną próbę opisu wielości, dodatkowo otwartą na wymiar aksjologiczny czy wręcz religijny (w swojej obszernej definicji „sieciowego neomediewalizmu” Grzegorz Lewicki pisze m.in., że nowe średniowiecze to „czas fragmentacji stosunków społecznych, w którym grupy religijne nabiorą politycznego i cywilizacyjnego znaczenia, a religijne i ideologiczne spoiwa tożsamościowe zostaną zrehabilitowane oraz będą proponowane jako gwarant cywilizacyjnej stabilności społeczeństw"65).

\section{Co robić? Możliwe postawy wobec strategii}

Czy powinniśmy się niepokoić tym, że rzeczywistość jest złożona, rozproszona i niesterowna, a przyszłość nieprzewidywalna? Wręcz przeciwnie - przekonuje Edwin Bendyk. I proponuje, byśmy byli nie futurofobami, ale futurofilami. Bo „przyszłość jest zasobem, którym można zarządzać w sposób racjonalny i zrównoważony, by realizować strategiczne cele" ${ }^{\prime \prime 66}$.

Skoro tak, to wobec przyszłej strategii miasta można przyjąć jedną z czterech poniższych postaw - każda z nich w ten czy inny sposób przewinęła się przez prace nad oboma opisywanymi wrocławskimi projektami:

1. Nie dajemy się przytłoczyć niepewności i lękom. Przyjmujemy, że najbardziej spolegliwe - bo

\section{Miasto. Pamięć i Przyszłość 1 (2016) ISSN 2543-621X}

pewne - są dotychczasowe trendy oraz oczekiwania mieszkańców (wszak są oni także - albo przede wszystkim - wyborcami). Powstaje strategia zakładająca implicite optymistyczny scenariusz dalszego toku zdarzeń globalnych. Spór między pesymizmem eksperta a oczekiwaniami mieszkańca zostaje rozstrzygnięty na korzyść tego ostatniego. Jednak wbrew pozorom nie zmniejsza to złożoności samej strategii: na pierwszy plan wysuwa się spór między zwolennikiem tezy o prymacie gospodarki a zwolennikiem tezy o prymacie jakości życia. Dużym plusem tego wariantu jest coś, co można by nazwać realizmem elektoralnym - daje on spore szanse na zbudowanie poparcia mieszkańców (a więc i radnych miejskich) dla dokumentu. Minusem jest faktyczna krótkoterminowość takiego podejścia - wszak scenariusze negatywne nie znikają, trzeba być wciąż gotowym na poważną modyfikację strategii na wypadek, gdyby optymizm zwiódł nas na manowce.

2. Z entuzjazmem przyjmujemy złożoność i zmienność systemu i niepewność przyszłości. Widzimy w tym szansę, a nie zagrożenie. Kontestujemy zrównoważony rozwój, pokładając nadzieję w jego przeciwieństwie - nierównowadze ${ }^{67}$. Inspiracją jest zaproponowana przez Josepha A. Schumpetera postać przedsiębiorcy-innowatora jako autora zmiany o charakterze skokowym,

\footnotetext{
64. „.... the organized intervention in collective affairs according to a standard of improvement" - ibidem, s. 3.

65. G. Lewicki, Powrót do przyszłości. Neomediewalizm, g/obalizacja, miasta, [w:] SdMP, t. 1. Cały tom 1 SdMP poświęcamy właśnie nowemu średniowieczu.

66. E. Bendyk, op.cit., s. 12-15.

67. Por. E. Bendyk, J. Hausner, Kultura i rozwój. Manifest, [w:] „Kultura i Rozwój", numer zerowy, Narodowe Centrum Kultury, grudzień 2015, http://nck.pl/media/attachments/317070/Kultura\%20 i\%20Rozw\%C3\%B3j\%20-\%200.2015\%20-\%20\%C5\%9Brodek.pdf, str. 7. I. Mironowicz, op. cit., s. 90.
} 
nieprzewidywalnej. Tak też pojmowany jest rozwój: jako ciąg takich właśnie skokowych zmian ${ }^{68}$. Nie jest on jednak sprowadzalny wyłącznie do sfery ekonomii. Jego istotnym elementem może być kultura, a ważną metodą - eksperymentowanie $^{69}$. Może mieć formę drobnych interwencji przestrzennych (lub społecznych w przestrzeni) - „byłby to scenariusz synergii, w którym wielu aktorom pozwoli się na rozwój według ich własnego planu, a nawet bez niego, w którym stwarza się warunki do emergencji, w którym wreszcie akceptuje się niepewność, jako nieodłączną cechę ewoluującego miasta" - wyjaśnia Izabela Mironowicz ${ }^{70}$. Plusem tego modelu jest bazująca na poczuciu zmienności elastyczność w podejściu do tkanki miejskiej, a zarazem ogromny nacisk na oddolną samoorganizację, współodpowiedzialność mieszkańców za miasto, zaufanie do zwykłych ludzi, chęć obdarowania ich maksymalnym poczuciem sprawstwa. Minusem może być nadmierna wiara w te właśnie zdolności samoorganizacyjne, niedocenianie zwykłej roszczeniowości

68. Zob. np. A. Glapiński, Schumpeterowska teoria przedsiębiorcy, czyli skąd się bierze pies, [w:] „Konsumpcja i Rozwój”, nr 1/2012 (2), http://cejsh.icm.edu.pl/cejsh/element/bwmeta1.element. desklight-4764d4cd-967f-4b3f-ae6b-bbf059fd5229/c/1.Glapinski_Schumpeterowska_teoria_przedsiebiorcy_czyli_skad_sie_bierze_pies.pdf, J. Hausner, Rozwój społeczno-gospodarczy, [w:] (red.) J. Hausner, A. Karwińska, J. Purchla, Kultura a rozwój, Narodowe Centrum Kultury, Warszawa 2013, http://nck.pl/media/2014-01-21/ podrecznik_copy1.pdf, s. 23-25.

69. E. Bendyk, J. Hausner, Kultura i rozwój..., op. cit.

70. I. Mironowicz, op. cit., str. 216-217.

71. Por. J. Waszkiewicz, Zorientowana na wartości strategia rozwoju jednostek samorzadu terytorialnego - koncepcja i przykład implementacji, [w:] „Prace Naukowe Instytutu Organizacji i Zarządzania Politechniki Wrocławskiej” nr 81, „Studia i Materiały” nr 23: Przedsiębiorstwa i instytucje w warunkach zmieniajacego się otoczenia. Część 2. Także $Ł$. Medeksza, Strateg jako krawiec miasta, rozmowa z Janem Waszkiewiczem, [w:] SdMP, t. 3, str. 183.

72. Zob. Ł. Medeksza, Strateg jako..., op. cit., str. 174-175.

73. Ibidem, s. 181.

74. W tym duchu utrzymany jest w zasadzie cały tom 3 SdMP. (która sprowadza się do oczekiwania, że to jednak władza będzie rozwiązywać problemy, realizować inwestycje i proponować pomysły) oraz skupienie się na działaniach prowadzonych w małej skali, co może okazać się nieadekwatne w obliczu dużych wyzwań (zwłaszcza negatywnych scenariuszy globalnych) czy choćby dużych ambicji (wyrażanych przez rozmaitych aktorów życia miasta).

3. W oceanie zmienności szukamy tego, co trwałe. Odwołujemy się do wartości. To właśnie one mają nam podpowiedzieć, jak postępować w przyszłości - choć nie wiemy, co nam ona przyniesie. Tak proponują Roman Galar i Jan Waszkiewicz ${ }^{71}$, twórcy koncepcji strategii zorientowanych na wartości, współautorzy m.in. pierwszych dwóch strategii Wrocławia oraz pierwszej strategii Dolnego śląska. Wartości - tłumaczy Jan Waszkiewicz - „są w jakiejś mierze zakodowane w kształcie przestrzennym miasta" i oddziałują na jego mieszkańców. Odczytujemy je „choćby za pomocą intuicji”. A ponieważ miasto to także wielość wartości, wybór jakiegoś konkretnego ich zestawu na potrzeby strategii ma zawsze dość arbitralny charakter - jest decyzją polityczną ${ }^{72}$. Tej orientacji na wartości blisko jest do wspomnianej wcześniej koncepcji nowego średniowiecza. Zresztą sam Waszkiewicz wprost odwołuje się właśnie do modelu miasta średniowiecznego ${ }^{73}$. Plusem tego wariantu jest chęć znalezienia tego, co trwałe, względnie ponadczasowe, budowy tożsamości, unikatowości miasta ${ }^{74}$ - w tym także jakiejś jego misji i/lub wizji, która może porwać i inspirować. Minusem może być nieunikniona arbitralność w wyborze wartości oraz trudność

Miasto. Pamięć i Przyszłość 1 (2016) ISSN 2543-621X 
w przełożeniu takiej strategii na bardziej techniczny język jej monitorowania i wdrażania, np. za pomocą ilościowych wskaźników.

4. Uznajemy, że skoro nic nie jest pewne, a światem rządzi chaos, to warto po prostu budować własną moc. Stawiamy sobie poprzeczkę wysoko - chcemy przewodzić. Bo strategia to - jak pisze Lawrence Freedman - „the art of creating power"75, czyli sztuka wzmacniania się, tworzenia mocy lub wręcz władzy. Albo „rachunek stosunków sił (lub manewrowanie nimi), powstający z chwilą, gdy możliwe jest wyodrębnienie podmiotu woli i władzy" - jak z kolei proponuje Michel de Certeau ${ }^{76}$. To podejście można nazwać Nietzscheańskim, przenika je wola mocy. Na jego gruncie pada pytanie: „Czego Wrocław może być liderem?"177. Podobna intuicja pojawia się na sam koniec strategicznej diagnozy miasta przygotowanej przez zespół Stanisława Korenika. Powołując się na Bohdana Jałowieckiego, dokument ten wskazuje, że „Wrocław powinien dążyć do tego, aby w optymalnym stopniu wypełniać rolę węzła w międzynarodowych sieciach". W praktyce oznacza to m.in. wzmacnianie tzw. dyrekcyjności, rozumianej jako „zgromadzenie zdolności i możliwości rozwoju funkcji strategicznych i decyzyjnych na najwyższym poziomie, zarówno w przypadku przedsiębiorstw, jak i innych instytucji"78. Z takich właśnie przesłanek wzięła się zaproponowana przez TUMW idea Wrocławia jako Wenecji nowego średniowiecza79, a więc miasta, które sięga po międzynarodowe przywództwo w czasach wielości i rozproszenia. Ważną inspiracją dla tego typu propozycji

Miasto. Pamięć i Przyszłość 1 (2016) ISSN 2543-621X 67 jest oczywiście tęsknota za osiągnięciem przez Wrocław statusu metropolii, czyli liczącego się globalnie ośrodka, który współpracuje z innymi podobnymi ośrodkami tworzącymi globalną sieć $^{80}$. Przynależność Wrocławia do Ligi Hanzeatyckiej w średniowieczu jest tu istotnym historycznym precedensem. Plusem tego modelu jest śmiałość, rozległość stawianych miastu celów, gotowość do porównywania się z najlepszymi - i doganiania ich. Minusem jest być może nadmierna wiara we własną moc sprawczą, przy niewystarczających potencjałach, co może narażać takie koncepcje na ostrą krytykę z pozycji "realistycznych” i/lub takich, które akcentują konieczność dbania przede wszystkim o sprawy małe, codzienne, w imię podnoszenia jakości życia mieszkańców miasta.

Który z tych modeli weźmie górę w 2017 r.? Jeśli nie wydarzy się nic dramatycznego, to zapewne ten pierwszy, ponieważ jest relatywnie najprostszy i zgodny z dotychczasowymi przyzwyczajeniami. Ma też jedną ważną cechę: najłatwiej da się dla niego pozyskać poparcie mieszkańców, bo bez problemu można go wypełnić przemawiającymi do myobraźni, prostymi pomysłami. Taka strategia

75. L. Freedman, op. cit., s. xii.

76. Michel de Certeau, Wynaleźć codzienność. Sztuki działania, Wydawnictwo Uniwersytetu Jagiellońskiego, Kraków 2008, s. 36. Cytowane definicje Freedmana i de Certeau przytaczam też we wprowadzeniu do SdMP: Ł. Medeksza, Strategie dla miasta przyszłości [w: SdMP, t. 0. Zob. także Ł. Medeksza, Pytanie o Wrocław przyszłości..., op.cit.

77. Jest ono punktem wyjścia refleksji na marginesie diagnoz Wrocławia w: Ł. Medeksza, Pytanie o Wrocław przyszłości..., op.cit.

78. Diagnoza Wrocławia, op.cit., str. 127.

79. Chodzi oczywiście nie o Wenecję współczesną, a tę z czasów swojej dawnej świetności. Tę ideę jako pierwszy sformułował Piotr Szymański, zainspirowany m.in. tomem 1 SdMP.

80. O metropolitalności i jej cechach pisze: I. Mironowicz, Modele..., op.cit., str. 63-70. 
może oczywiście okazać się ryzykowna, gdyby doszło do jakichś globalnych turbulencji. Otwarte pozostaje pytanie, na ile może ona spełnić wyższe, śmielsze aspiracje wrocławian - choćby te wyrażone poprzez poparcie udzielone trzem spośród pięciu roboczych wizji przedstawionych w cytowanym wcześniej badaniu opinii z lata 2016 r. ${ }^{81}$. Wszak można z wyników owej ankiety wysnuć i taki wniosek, że polityka rzeczy małych i koncentracja wyłącznie na poprawie jakości życia mieszkańców nie jest jedynym horyzontem wyobraźni i oczekiwań wrocławian. Chcemy znacznie więcej.

Wyzwaniem pozostaje strategiczna misja Wrocławia ${ }^{82}$. Dotychczasowa - zapisana w strategiach z 1998 i 2006 r. - jest cytatem z Jana Pawła II: „Wrocław miastem spotkania - miastem, które jednoczy". To na jej kanwie powstało promocyjne hasło Wrocławia - "Miasto spotkań". Jednak jego słaby wynik w badaniu z lata 2016 r. otworzył możliwość zmiany misji strategicznej. Zwolennicy tej dotychczasowej słusznie podkreślają, że hasło "Miasto spotkań” wypaczyło jej treść ${ }^{83}$. Zatem słaby wynik hasła nie musi prowadzić do zmiany misji, bo to dwa całkiem różne sformułowania. Co więcej, dodatkowym atutem misji jest zawarte w niej określenie "Miasto, które jednoczy”, które może odnosić się nie tylko do np. jednoczenia kultur i światopoglądów, ale także do wiązania w całość (względnie
- równoważenia) rozproszonej wielości, złożoności, o których pisałem wcześniej ${ }^{84}$. Z tego punktu widzenia ów jednoczący Wrocław mógłby być miastem wielu perspektyw, szukającym harmonii, nie zaś dysonansów w powszechnej polifonii. Są to, oczywiście, wciąż dość luźne rozważania. Ostateczny kształt misji powinien rozstrzygnąć się w pierwszej połowie 2017 r.

Łukasz Medeksza (ur. 1973), Kulturoznawca. Sekretarz powołanego przez Prezydenta Wrocławia zespołu opracowujacego nowa strategię miasta (od 2016). W 2016 r. koordynator projektu Foresight Społeczny Wrocław 2036/2056 r. w ramach Europejskiej Stolicy Kultury 2016, w tym redaktor prowadzacy publikacji Strategie dla Miasta Przyszłości. Członek Zarządu Głównego Towarzystwa Urbanistów Polskich (od 2015), sekretarz (2009-2012), wiceprezes (2012-2015) wrocławskiego oddziału PUP. Od 2016 r. członek-założyciel Stowarzyszenia INTBAU-Polska. Członek Rady ZIT WrOF (od 2015). W latach 2010-2016 pracował w Urzędzie Marszałkowskim Województwa Dolnośląskiego. Współautor (wraz z Katarzyna Uczkiewicz) książki Ziemie Zachodnie: zrób to sam. Wywiady opublikowane w kwartalniku „Pamięć i Przyszłość" w latach 2008-2013 (2015). W latach 20002010 dziennikarz, publicysta, redaktor dolnośląskich mediów. W Instytucie Kulturoznawstwa Uniwersytetu Wrocławskiego pisze doktorat o samorzadowych strategiach rozwoju zorientowanych na wartości.

81. J. Pluta, Mieszkańcy na temat..., op.cit.

82. Piszę o tym także w: $Ł$. Medeksza, Pytanie o Wrocław przyszło-

ści..., op. cit.

83. Por. M. Pięta-Kanurska, Scenariusz 4: Miasto spotkań, stawiajace na duże imprezy i potencjały zewnętrzne, [w:] SdMP, t. 0; M. Mutor, Wrocław - miasto spotkań wartości, [w:] Wszystko, Co Najważniejsze, 2 XI2016., https://wszystkoconajwazniejsze.pl/ marek-mutor-wroclaw-miasto-spotkan-wartosci/.

84. Taki pomysł pojawił się w trakcie rozmowy z Małgorzatą Piętą-Kanurską i Janem Waszkiewiczem.

Miasto. Pamięć i Przyszłość 1 (2016) ISSN 2543-621X 


\section{Bibliografia}

\section{Akty prawne}

Uchwała nr XVII/323/15 Rady Miejskiej Wrocławia z dnia 15 października 2015 r. w sprawie przystąpienia do sporządzenia strategii rozwoju Wrocławia pod nazwą "Strategia Wrocław 2030", http://wrosystem.um.wroc.pl/beta_4/webdisk/180716/0323ru07.pdf (uzasadnienie uchwały: http://bip.um.wroc.pl/uploads/files/Sesje_porzadki_7_kadencja/316-15\%20uzasadnienie.pdf). Zarządzenie nr 5702/16 Prezydenta Wrocławia z dnia 9 listopada 2016 r. w sprawie powołania zespołu ds. Strategii Wrocławia 2030, http://wrosystem.um.wroc.pl/beta_4/webdisk/187841/5702zp16.pdf

\section{Publikacje, artykuły naukowe}

Bendyk, E., Foresight. Sztuka i techniki zarządzania przyszłością, Instytut Badań nad Gospodarką Rynkową, Gdańsk 2013, http://www.ibngr.pl/content/ download/1474/16065/file/Foresight

Sztuka_i_techniki_zarzadzania_przyszloscia.pdf Bendyk E., Hausner J., Kultura i rozwój. Manifest [w:] „Kultura i Rozwój”, numer zerowy, Narodowe Centrum Kultury, grudzień 2015, http://nck.pl/ media/attachments/317070/Kultura\%20i\%20Rozw\%C3\%B3j\%20-\%200.2015\%20-\%20\%C5\%9Brodek.pdf

de Certeau M., Wynaleźć codzienność. Sztuki działania, Wydawnictwo Uniwersytetu Jagiellońskiego, Kraków 2008

Diagnoza Wrocławia, Wrocław, sierpień-wrzesień 2016, tekst niepublikowany, w posiadaniu autora Dworzański P., Grochowski M., Gubański K., Iwańczak B., Świętochowska A., Wereta K., Wojnar K., Diagnoza potencjału kulturalnego Wrocławia.
Raport z realizacji pakietu zadań analityczno-badawczych i konsultacyjnych, Warszawa, sierpień 2016, materiał roboczy, niepublikowany, w posiadaniu autora

Feyerabend P., Against Method, Verso, 1993 Freedman L., Strategy. A history, Oxford University Press 2013

Gajny I., Dębek M., Świdnicka A.D. 2056: handlowy kręgosłup metropolii [w:] Miasto piękna i charakteru, red. I. Gajny, tom 3 [w:] Strategie dla Miasta Przyszłości, red. Ł. Medeksza, http://www.miastoprzyszlosci. wroclaw.pl/img/posts/Foresight_Tom3.pdf

Glapiński A., Schumpeterowska teoria przedsiębiorcy, czyli skąd się bierze pies [w:] „Konsumpcja i Rozwój", nr 1/2012 (2), http://cejsh.icm.edu.pl/ cejsh/element/bwmeta1 .element.desklight-4764d4cd-967f-4b3f-ae6b-bbf059fd5229/c/1.Glapinski_Schumpeterowska_teoria_przedsiebiorcy_czyli_skad_sie_bierze_pies.pdf

Hassan G., Mean M., Tims C., The Dreaming City: Glasgow 2020 and the power of mass imagination, Demos, London 2007

Hausner J., Rozwój społeczno-gospodarczy [w:] (red.) J. Hausner, A. Karwińska, J. Purchla, Kultura a rozwój, Narodowe Centrum Kultury, Warszawa 2013, http://nck.pl/media/2014-01-21/podrecznik_copy1. pdf

Hemel Z., Open Planning for a Liveable Amsterdam 2004-2011, tekst w posiadaniu autora

Karabon K., Karabon M., Migawki z diagnozy Wrocławia, Konsultacje: Filar P., Medeksza Ł., Wrocław, grudzień 2016, prezentacja niepublikowana Kasprzak T., Fantazmaty, narracje, symbole. Oddolne scenariusze przyszłości Wrocławia - głos mieszkańców [w:] Wrocław. Rewers. Scenariusze miasta przyszłości, red. K. Kamińska, M. Pięta-Kanurska, A. Snitsaruk, tom 0 [w:] Strategie dla Miasta Przyszłości, red. Ł. 
Medeksza, http://www.miastoprzyszlosci.wroclaw. pl/img/posts/Foresight_Tom0.pdf

Lewicki G., Powrót do przyszłości. Neomediewalizm, globalizacja, miasta [w:] Miasta w nowym średniowieczu, red. G. Lewicki, tom 1 [w:] Strategie dla Miasta Przyszłości, red. Ł. Medeksza, http://www. miastoprzyszlosci.wroclaw.pl/img/posts/Foresi-

ght_Tom1.pdf

Lorens P., Wspótczesne trendy zmian w strukturze i funkcjonowaniu miast [w:] (red.) P. Lorens, I. Mironowicz, Wybrane teorie współczesnej urbanistyki, Akapit-DTP, Gdańsk 2013

Medeksza Ł., Fenomen wrocławskiej Wyspy Stodowej: starcie modeli użytkowania przestrzeni publicznej [W: „CZłowiek i Środowisko”, 39(2) 2015, https:// czlowiekisrodowisko.igpim.pl/wp-content/uploads/2016/06/04-Medeksza.pdf

Medeksza Ł., Foresightowe scenariusze przyszłości dla Wrocławia [w:] Wrocław. Rewers. Scenariusze miasta przyszłości, red. K. Kamińska, M. Pięta-Kanurska, A. Snitsaruk, tom 0 [w:] Strategie dla Miasta Przyszłości, red. Ł. Medeksza, http://www.miastoprzyszlosci. wroclaw.pl/img/posts/Foresight_Tom0.pdf

Medeksza Ł., Pytanie o Wrocław przyszłości - wstępne uwagi do diagnoz i analiz miasta, tekst przygotowany w ramach Foresightu Społecznego Wrocław 2036/2056, niepublikowany

Medeksza Ł., Mironowicz I., Nowe modele zarzqdzania terytorialnego [w:] „Biuletyn KPZK PAN”, nr 257-258 / 2015, http://bkpzk.czasopisma.pan.pl/ images/data/bkpzk/wydania/No_257_258_2015/ 4-Medeksza.pdf

Miasta w nowym średniowieczu, red. G. Lewicki, tom
1 [w:] Strategie dla Miasta Przyszłości, red. Ł. Medeksza, http://www.miastoprzyszlosci.wroclaw.pl/img/ posts/Foresight_Tom1.pdf

Miasto mądre i samodzielne, red. T. Bojęć, tom 4 [w:] Strategie dla Miasta Przyszłości, red. Ł. Medeksza, http://www.miastoprzyszlosci.wroclaw.pl/img/ posts/Foresight_Tom4.pdf Miasto piękna i charakteru, red. I. Gajny, tom 3 [w:] Strategie dla Miasta Przyszłości, red. Ł. Medeksza, http://www.miastoprzyszlosci.wroclaw.pl/img/ posts/Foresight_Tom3.pdf

Między miłością a polityką, red. M. Żakowska, tom 2 [w:] Strategie dla Miasta Przyszłości, red. Ł. Medeksza, http://www.miastoprzyszlosci.wroclaw.pl/img/ posts/Foresight_Tom2.pdf

Mironowicz I., Modele transformacji miast, Oficyna Wydawnicza Politechniki Wrocławskiej, Wrocław 2016

Mutor M., Wrocław - miasto spotkań wartości [w:] Wszystko, Co Najważniejsze, 2.11.2016., https://wszystkoconajwazniejsze.pl/ marek-mutor-wroclaw-miasto-spotkan-wartosci/ Nederveen Pieterse J., Development Theory. Second Edition, SAGE, Los Angeles, London, New Delhi, Singapore, Washington DC, 2015

Piattoni S., The Theory of Multi-level governance. Cenceptual, empirical, and normative challenges, Oxford University Press, 2010

Pięta-Kanurska M., Scenariusz 4: Miasto spotkań, stawiajace na duże imprezy i potencjały zewnętrzne [W:] Wrocław. Rewers. Scenariusze miasta przyszłości, red. K. Kamińska, M. Pięta-Kanurska, A. Snitsaruk, tom 0 [w:] Strategie dla Miasta Przyszłości, red. Ł. 
Medeksza, http://www.miastoprzyszlosci.wroclaw.

pl/img/posts/Foresight_Tom0.pdf

Pluta J., Mieszkańcy na temat bieżacej oceny potencjału Wrocławia i strategii rozwojowych miasta. Prezentacja wyników badań nad założeniami Strategii Wrocław 2030, http://www.wroclaw.pl/strategia-rozwoju-wroclawia-2030/files/Wroclaw-2030-prezentacja-media-3.pdf - prezentacja przedstawiona 17.10.2016

Vinge V., The Coming Technological Singularity: How to Survive in the Post-Human Era, VISION-21 Symposium sponsored by NASA Lewis Research Center and the Ohio Aerospace Institute, March 30-31, 1993, http://www-rohan.sdsu.edu/faculty/vinge/ misc/singularity.html

Waszkiewicz J., Zorientowana na wartości strategia rozwoju jednostek samorzadu terytorialnego - koncepcja i przykład implementacji [w:] „Prace Naukowe Instytutu Organizacji i Zarządzania Politechniki Wrocławskiej” nr 81, "Studia i Materiały” nr 23: „Przedsiębiorstwa i instytucje w warunkach zmieniającego się otoczenia". Część 2

Waszkiewicz J., Medeksza Ł., Strateg jako krawiec miasta, rozmowa z Janem Waszkiewiczem [w:] Miasto piękna i charakteru, red. I. Gajny, tom 3 [w:] Strategie dla Miasta Przyszłości, red. Ł. Medeksza, http://www. miastoprzyszlosci.wroclaw.pl/img/posts/Foresight_Tom3.pdf Wrocław. Rewers. Scenariusze miasta przyszłości, red. K. Kamińska, M. Pięta-Kanurska, A. Snitsaruk, tom 0 [w:] Strategie dla Miasta Przyszłości, red. Ł. Medeksza, http://www.miastoprzyszlosci.wroclaw.pl/img/ posts/Foresight_Tom0.pdf Wrocławska Strategia Edukacyjna, Wrocław 2015, http://wrosystem.um.wroc.pl/beta_4/webdisk/179742/0271ru07z.pdf 